\title{
Spectrophotometric Estimation of Metal Ions and Nutrient Value of Formulae Milk and Baby Foods Available in Pakistan Under Different Brand Names
}

\section{Amina Arif ${ }^{1}$, Bushra Khan ${ }^{2}$, Khizra Majeed², Muhammad Saqib Shahzad ${ }^{1}$, Muhammad Shahid NADEEM ${ }^{3}$, RafiQue AHMED ${ }^{4}$}

${ }^{1}$ Faculty of Life Sciences, University of Central Punjab 1-Khayaban-E-Jinnah Road, Johar Town, Lahore 54000 Pakistan; ${ }^{2}$ Lahore College for Women University, Lahore 54000 Pakistan; ${ }^{3}$ Department of Biochemistry, Faculty of Science, Building No. A-90, King Abdulaziz University Jeddah 21589, Saudi Arabia; ${ }^{4}$ Govt. Kot Khawaja Saeed Teaching Hospital, Lahore, Pakistan.

\begin{abstract}
The present study describes the concentrations of contaminating trace metals like iron, copper, zinc, cobalt, nickel and magnesium; toxic metals including cadmium and lead, micro nutrients including sodium and potassium among 27 different infant milk and baby foods. The samples were analyzed by atomic absorption spectrometer prior to acid digestion. The levels of elements in analyzed samples were found to be under legal limits. Nickel concentration was found to be higher in some infant food that ranged $0.008-0.09 \mathrm{mg} / \mathrm{g}$ and in infant cereals ranged $0.005-0.01 \mathrm{mg} / \mathrm{g}$. The range of investigated metals zinc, iron, copper, cadmium, lead, sodium, potassium and magnesium, was $0.0005-$ $0.12 \mathrm{mg} / \mathrm{g}, 0.002-0.13 \mathrm{mg} / \mathrm{g}, 0.0005-0.45 \mathrm{mg} / \mathrm{g}, 0.001-0.04 \mathrm{mg} / \mathrm{g}, 0.001-0.21 \mathrm{mg} / \mathrm{g}$ and $0.01-1-2.82 \mathrm{mg} / \mathrm{g}, 0.03-9.9$ $\mathrm{mg} / \mathrm{g}$, and $0.01-0.046 \mathrm{mg} / \mathrm{g}$ in infant foods and cereals. The estimated intake of these metals were within recommended tolerable levels of these elements. Protein content was determined by Lowry's method that ranged $0.02-2.1 \mathrm{mg} / \mathrm{g}$. Moreover, infant formulas were analyzed for the bacterial load (probiotics) and it was found that most of the products analyzed in this study contained a sufficient amount of probiotic bacteria in them. Our data can guide the parents and physicians in the selection of baby foods in Pakistan.
\end{abstract}

Keywords $\mid$ Atomic absorption spectroscopy, Flame photometry, Infant formulae, Baby food, Heavy metals

\footnotetext{
Editor | Muhammad Nauman Zahid, Quality Operations Laboratory, University of Veterinary and Animal Sciences, Lahore, Pakistan.

Received | December 05, 2017 Accepted | January 25, 2018; Published | May 05, 2018

*Correspondence | Amina Arif, University of Central Punjab 1-Khayaban-E-Jinnah Road, Johar Town, Lahore 54000 Pakistan; Email: draminaarif@gmail.com Citation | Arif A, Khan B, Majeed K, Shahzad MS, Nadeem MS, Ahmed R (2018). Spectrophotometric estimation of metal ions and nutrient value of formulae milk and baby foods available in pakistan under different brand names. S. Asian J. Life Sci. 6(1): 14-21.

DOI | http://dx.doi.org/10.17582/journal.sajls/2018/6.1.14.21

ISSN | 2311-0589
}

Copyright (C) 2018 Amina et al. This is an open access article distributed under the Creative Commons Attribution License, which permits unrestricted use, distribution, and reproduction in any medium, provided the original work is properly cited.

\section{INTRODUCTION}

$\mathrm{T}$ he nutrient pattern has excellent value, especially in early developmental stages in pursuing a healthy body from childhood to adolescence. Infant formulae are widely used as breastmilk substitutes and play a crucial role as the main source of nutrients (Rodriguez et al., 2000; Briefel et al., 2004). Breastmilk has ideal food supplements for newborn and has retained an immensity since the ancient to modern times. Breast milk consists of ideal components like antibodies, enzymes, anti-inflammatory factors, antimicrobial agents and fatty acids which are very crucial for brain development (Van't Land et al., 2010; Gasmalla et al., 2013). In the modern world, breast milk is replaced by milk and formula products. In these replacements, there always remains a threat for the toxicity of various contaminants and deficiency of nutrients (Demirezen and Uruç, 2006). On the other hand, the exposure to hazardous metals in the environment has affected breast milk (Chao et al., 2014; Sanders et al., 2015; Ahmad et al., 2017). The natural cow milk available on the market has the heavy metal toxicity of Lead $(\mathrm{Pb})$ and Cadmium $(\mathrm{Cd})$ above the permissible limits emphasizing on the need for safe food materials at an early age (Pavlovic et al., 2004; Ismail et al., 2017). Manganese is an essential element, but elevated-levels in foods can be toxic mainly for children 
(De Amorim et al., 2011). A prebiotic can be explained as a non- digestible food component which initiates specific changes in the activity of the gastrointestinal flora with advantageous effects on host well-being and health (Donovan and Gibson, 2009; Kristensen et al., 2016). The intake of probiotics in the follow-up formulae, and beyond early infancy, is associated with some clinical advantages, reducing the risk of gastrointestinal disorders, decreased use of antibiotics use and a lower frequency of colic irritability (Ackerberg et al., 2012). The FAO /WHO joint committee prepared guidelines for the study of the dietary intake of chemical contaminants including heavy metals. In the developing countries like Pakistan, the quality assurance system for food products is often poorly followed. The present study was aimed at screening the levels of various essential nutrients and toxic metal ions in various categories of baby foods available in the local market under different brand names.

Table 1: List of samples

\begin{tabular}{ll} 
Milk Based Infant Formula \\
\hline S1 & Nan1 \\
\hline S2 & Lactogen 1 \\
\hline S3 & Meiji 1 \\
\hline S4 & Similac \\
\hline S5 & Morinaga1 \\
\hline S6 & Nan2 pro \\
\hline S7 & Lactogen 2 \\
\hline S8 & Mieji 2 \\
\hline S9 & Similac 2 \\
\hline S10 & Nan vanilla \\
\hline Cereal Based Baby Food \\
\hline S11 \\
\hline S12 & Cerelac rice \\
\hline S13 & Cerelac 3 fruits \\
\hline S14 & Yogart+mango+orange \\
\hline S15 & Cerelac apple and orange \\
\hline S16 & Cerelac wheat and honey \\
\hline S17 & Cerelac strawberry \\
\hline Mixed Adult Baby Food & Cerelac wheat \\
\hline S18 & Horlicks wheat \\
\hline S19 & Complan chocolate \\
\hline S20 & Complan strawberry \\
\hline S21 & Complan vanilla \\
\hline S22 & Horlicks chocolate \\
\hline S23 & Kallyg'schocos \\
\hline S24 & Horlicks junior \\
\hline S25 & Nidobunyad \\
\hline S26 & bourn vita chocolate \\
\hline S27 & Milo \\
\hline & \\
\hline
\end{tabular}

\section{MATERIALS AND METHODS}

Twenty-seven baby food samples were randomly collected from different areas in Lahore, Pakistan in their original packings. Samples were further divided into 3 groups: milk-based, cereal-based infant food and mixed baby foods. Chemicals in practice were of analytical grade.

\section{Acid Digestion Method}

All the glassware cleaned with $10 \% \mathrm{HNO}_{3}$ and distilled water was used for analysis of samples. $0.2 \mathrm{~g}$ of each sample was weighed in triplicates and digested with $1: 2$ of $\mathrm{HNO}_{3}$ and $\mathrm{H}_{2} \mathrm{O}_{2}$ on a hot plate at $70^{\circ} \mathrm{C}$ in a fume hood, till reduced to tiny amounts. Allowed to cool down and then suspended in $5 \mathrm{ml}$ of $2 \mathrm{M} \mathrm{HNO}_{3}$ after that filtered and further diluted with distilled water to make a final volume of $10 \mathrm{ml}$. The blanks were made in the same way without using any sample. The filtrate was stored in properly labeled and sealed plastic bottles. All the samples were prepared in triplicates. The metal contents were then examined by Flame Atomic Absorption spectrophotometer.

\section{Determination of Metal Contents by Atomic Absorption Spectrophotometry}

Stock solution (1000 ppm) of metals $\mathrm{Cd}, \mathrm{Mg}, \mathrm{Fe}, \mathrm{Pb}, \mathrm{Cu}$, $\mathrm{Fe}, \mathrm{K}, \mathrm{Na}$, and $\mathrm{Zn}$ were prepared. For calibration dilutions were made from the stock solutions at $1.00 \mathrm{ppm}, 2.00 \mathrm{ppm}$, $3.00 \mathrm{ppm}, 4.00 \mathrm{ppm}, 5.00 \mathrm{ppm}$. Identification of trace elements was done by atomic absorption spectrophotometry (Aleixo and Nobrega, 2003). For each element, the accuracy, precision, selectivity, and sensitivity were verified by using Perkin Elmer Double Beam 2380 Atomic Absorption Spectrophotometer with a reference sample.

\section{Protein Determination by Lowry's Method}

For determination of protein in the baby feed samples the method was used as explained by Waterborg (2002). Bovine Serum Albumin (BSA) was used up to plot calibration curve. Absorbance was taken at $660 \mathrm{~nm}$ followed by quantification with a graph plot.

\section{Estimation of Prebiotics}

Five millilitres LB (Luria-Bertani) broth $(0.5 \mathrm{~g} \mathrm{NaCl}, 0.5 \mathrm{~g}$ yeast extract and1g of tryptone) was prepared in the test tubes and autoclaved for sterilization. Addition of $2 \mathrm{mg}$ of each sample was done in these test tubes under controlled conditions, then placed in a shaking incubator for 24 hours at $37^{\circ} \mathrm{C}$ for attaining maximum growth. To one set of the test tubes, antibiotic ciprofloxacin was added and the other set was kept without antibiotic. Ciprofloxacin was added for suppression of growth of bacteria other than the required one in each sample. Optical density $600 \mathrm{~nm}$ was measured at 1, 2, 3, 4, 5 hours of incubation using UV visible spectrophotometer. 
STATISTICAl Analysis

The data was analyzed by using Excel data sheets. The simple percentages plus mean values $+\mathrm{SD}$ of the heavy metals were calculated.

\section{RESULTS AND DISCUSSION}

\section{Metal Concentrations in Infant Starter} Formula a and Cereal Based Baby Food

Zinc an important trace element serves as a cofactor for many enzymes. The average concentration of zinc in different starter formulations alternated between 2.3-4.1 $\mathrm{mg} / 100 \mathrm{~g}$ with highest concentrations detected in Similac1 and lowest in Lactogen1 (Figure 1A). The concentration of zinc in all investigated materials meant for 0-6 month babies was found within permissible limits. Infant foods are usually fortified with iron to meet the body's nutritional requirements, in this study the concentration levels of iron ranged between $5.3-5.9 \mathrm{mg} / 100 \mathrm{~g}$ with highest concentrations found in Nan 1 of $5.9 \mathrm{mg} / 100 \mathrm{~g}$ (Figure 1A). Aluminum is a toxic metal and accumulates especially in the lungs, liver, thyroid and brain. It has been reported that infants are more susceptible to exposure to $\mathrm{Al}$ than adults because of their immature systems. The proposed the provisional tolerable weekly intake (PTWI) is $0.7 \mathrm{mg} \mathrm{Al} / 100$ $\mathrm{g}$ body weight (Sipahi et al., 2006). No Aluminum toxicity was observed in the infant formula analyses in this research. Copper concentration was different (ranging from 0.12 to $0.19 \mathrm{mg} / 100 \mathrm{~g}$ ) in different brands of milk. The highest amount was detected in Similac1 that was $0.19 \mathrm{mg} / 100 \mathrm{~g}$ of milk. In comparison with the results of this study concentration values of copper in Similac 1 and Lactogen 1 were slightly below the recommended values (Figure 1A). Nickel was completely absent in all samples, so these samples were free from nickel (Figure 1A). Cadmium was found in very small quantities i.e. $0.01-0.07 \mu \mathrm{g}$ $/ g$, which are within the permissible limits in almost all of the investigated food samples. Contamination of milk samples with lead has been a serious health hazard in the past which poses a detrimental effect on the mental health of the baby, as previous studies highlighted raised levels of lead in milk samples during the manufacturing process. The major reason of contamination of cow's milk may be due to increased exposure of lactating cows to lead to environmental pollution, consumption of contaminated food and water (Okada et al., 1997). Moreover, one of the striking revelations of raw milk contamination with lead might be its storage in metallic lead soldered cans (El-Batanoni and Abo El-Ata, 1996). The concentration levels of lead in these samples were within permissible limits imposing no danger to the infant. Sodium an essential electrolyte in the body is required to carry out proper homeostasis, as a result of the mean concentrations in different samples of this study ranged between $110-160 \mathrm{mg} / 100 \mathrm{~g}$ which fall within the permissible levels, with Meiji1 showing the maximum value (Figure 1A). Potassium and magnesium showed average concentration in the range of $240-450 \mathrm{mg} / 100 \mathrm{~g}$ and $240-450 \mathrm{mg} / 100 \mathrm{~g}$ respectively, with Lactogen 1 having the highest concentration of potassium and Morinaga showing highest value for magnesium. Metal concentration of zinc in follow up formula ranged from $4.3-12 \mathrm{mg} / 100 \mathrm{~g}$, with the highest concentration of $12 \mathrm{mg} / 100 \mathrm{~g}$ found in Nan vanilla. This concentration was slightly above the permissible limits (given in Figure 1B), Nickel was not detected in any of the samples under study (Figure 1B). Cadmium and lead showed minute negligible detection (Figure 1B) favoring to a more reliable recommendation of samples for use by infants. Sodium was higher in concentration in samples of Lactogen 2, Nan vanilla and Similac 2, whereas there were lower levels of Potassium in Similac 2 and Nan vanilla (Figure 1B). Meiji 2 and Lactogen 2 have reasonable and appropriate levels of all metals.

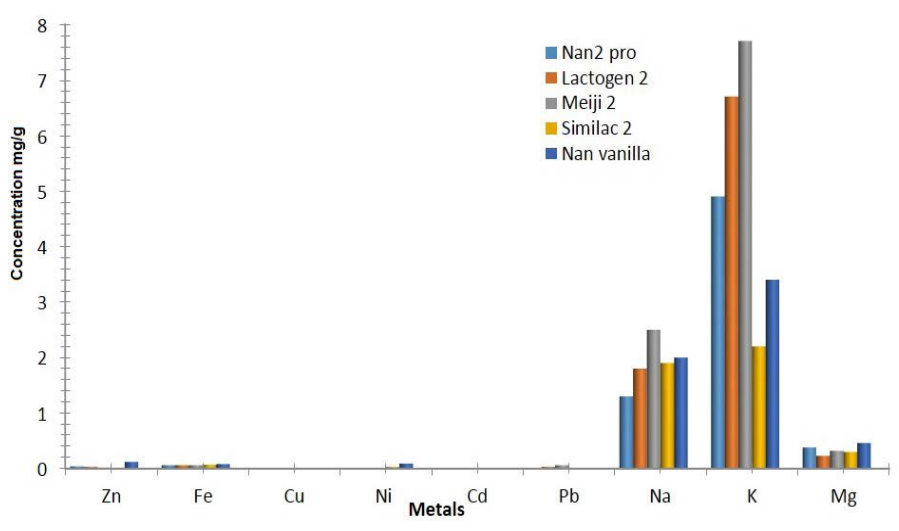

Figure 1A: Graphical representation of Metal concentrations in infant starter formula and cereal based baby food.

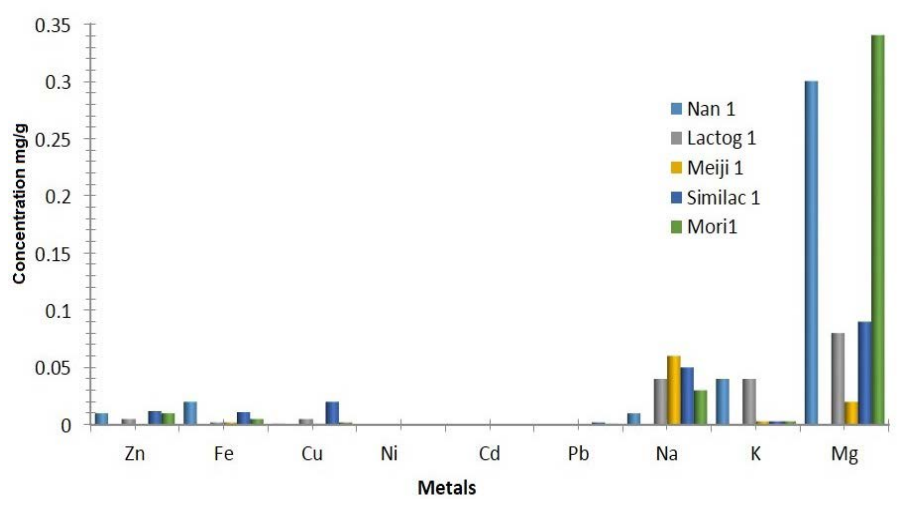

Figure 1B: Graphical representation of metal concentrations in follow up Infant formula.

\section{Metal Concentrations in Cereal Based Baby Food}

Cereal based food gathers much attention being the major source of diet in infants possessing highly essential nutrients required by the infant which can be provided other than milk. Zinc was detected from 4.3 to $15 \mathrm{mg} / 100 \mathrm{~g}$ in 
various samples, with the highest concentration found in Nan vanilla Cerelac 3 fruits and Cerelac rice with values of 9.93 and $15 \mathrm{mg} / 100 \mathrm{~g}$ respectively (Figure 2). Copper is found in reasonable and permissible amounts in all the samples of Cerelac wheat and honey, Cerelac yogurt mango, Cerelac apple and orange, Cerelac 3F (Figure 2). Nickel exhibited highest value in Cerelac $3 \mathrm{~F}$ and lowest in Cerelac wheat and honey. Sodium showed maximum concentration in Cerelac apple and orange and lowest in Cerelac rice, whereas Potassium was lower in Cerelac rice too, but increased levels were seen in samples of Cerelac wheat and honey (Figure 2).

Table 2: Recommended daily intake of metals $\mathrm{mg} /$ day for 0-6 and 6-12 months infants

\begin{tabular}{|llll|} 
Sr no. & Metals & \multicolumn{2}{l|}{ Recommended daily intake [mg/day] } \\
\hline 1 & & 0-6 months & $\mathbf{6 - 1 2}$ months \\
\hline 2 & Zinc & 5.3 & 5.6 \\
\hline 3 & Copper & 6 & 8.5 \\
\hline 4 & Nickel & $0.37-0.62$ & 0.6 \\
\hline 5 & Cadmium & 0.005 & 0.12 \\
\hline 6 & Lead & 0.003 & 0.005 \\
\hline 7 & Sodium & 120 & 0.003 \\
\hline 8 & Potassium & 700 & 370 \\
\hline 9 & Magnesium & 36 & 800 \\
\hline
\end{tabular}

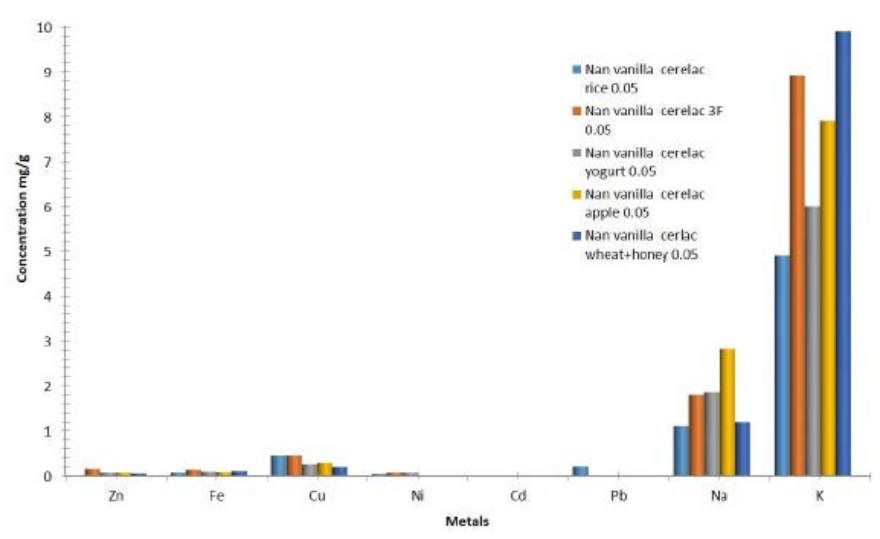

Figure 2: Graphical presentation of metal concentration in cereal based baby food.

\section{Metal Concentration in Baby Food Above 1 YEAR}

The concentration of Zinc present in baby food follows the sequence from highest to lowest in the order as Horlicks wheat, Complan chocolate, Complan strawberry, Complan vanilla, with highest in horlicks wheat of about $0.13 \mathrm{mg} / \mathrm{g}$ (Figure 3A). Iron is an essential group in the transition metals with its valued significance in the fortification of foods to meet the nutritional needs. The concentration of iron ranged between $0.6-0.29 \mathrm{mg} / 100 \mathrm{~g}$, with highest concentrations in horlicks wheat of 0.29 and lowest in
Complan strawberry and Complan vanilla of $0.6 \mathrm{mg} / \mathrm{g}$ (Figure 3A). Copper resulted in appropriate values for all kinds of baby food. Nickel was not identified in many samples and if reported in any study had negligible levels of consumption. Lead content was zero in milo but higher in Complan chocolate above the allowed levels (Figure 3A). Sodium ranged between $0.43-3.0 \mathrm{mg} / \mathrm{g}$ and a much lower level of milo chocolate flavored milk (Figure 3B). Potassium showed highest levels in samples of Complan chocolate, horlicks wheat, Complan vanilla, horlicks junior and in milo and lower levels in Complan strawberry, Nido Bunyad, bornvita chocolate. In horlicks wheat and Complan strawberry potassium demonstrated a high rise with $8.9 \mathrm{mg} / \mathrm{g}$. Magnesium ranged from $1.9-5.4 \mathrm{mg} / \mathrm{g}$ and $6.4 \mathrm{mg} / \mathrm{g}$ respectively according to this study, Figure $3 \mathrm{~A}$ and $\mathrm{B}$.

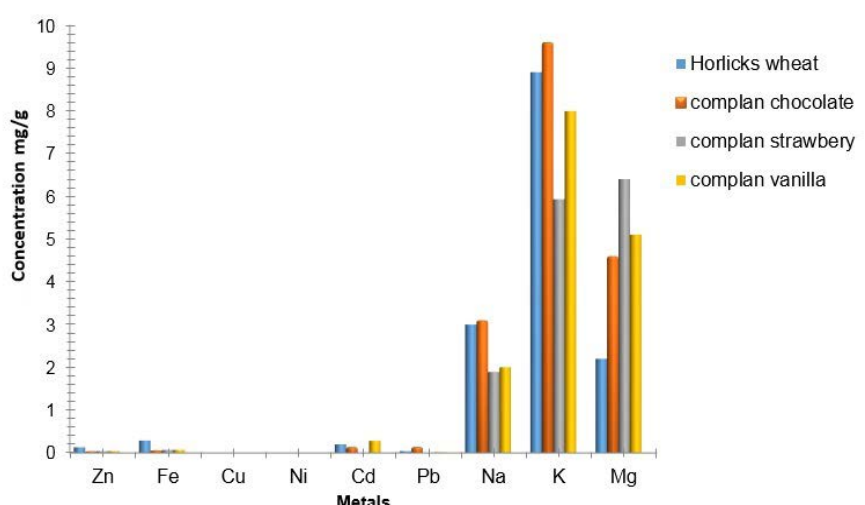

Figure 3-A: Graphical presentation of metal concentration in cereal based baby food.

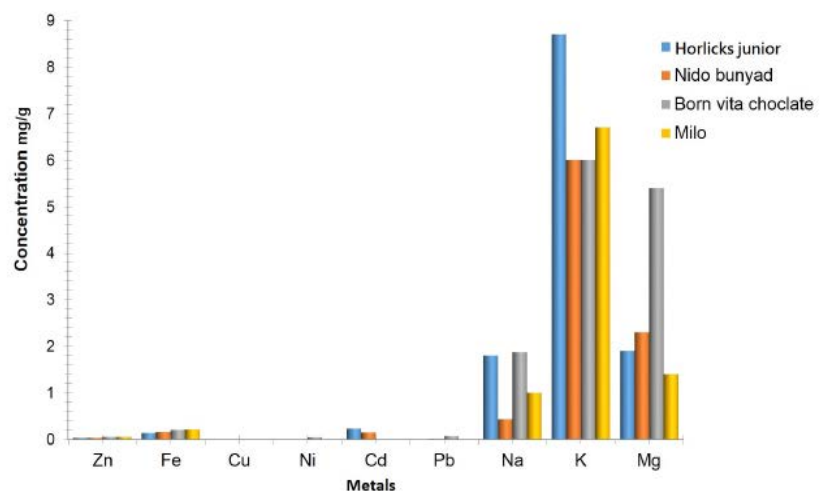

Figure 3-B: Graphical presentation of metal concentration in baby food.

\section{Calculation of Daily Intake of the Analyzed Metals}

Mean dietary intake of infant formula was calculated by taking into consideration the age of infants. For 0-6 month's old baby, the average consumption of infant formula is 135 $\mathrm{g}$ having an average weight of body $7.5 \mathrm{~kg}$ while the infants of 6-12 months with average weight $10 \mathrm{~kg}$ consume 164 g. Estimated daily intake in Nan 1, Lactogen 1, Meji1, Similac 1 and Morinaga 1 is 5.25, 4.32, 4.45, 5.53 and 3.31 
$\mathrm{mg} /$ day respectively. Whereas suggested intake of zinc in 0-6 months old infants is $5.3 \mathrm{mg} /$ day according to WHO/ FAO. So, the results showed that level of zinc is in conceivable limits within these samples. The estimated intake of iron in these samples is higher than suggested intake value that is $6 \mathrm{mg} /$ day. These values lie beyond the permissible level of iron. Permissible range of copper intake is $0.35-0.62 \mathrm{mg} /$ day. Mieji 1 infant formula did not show the presence of lead whereas estimated intake for remaining sample is greater than suggested that is $0.005 \mathrm{mg} /$ day. Sodium and potassium recommended intake is $120 \mathrm{mg} /$ day and $700 \mathrm{mg} /$ day for infants according to European Union. But the estimated intake is slightly greater but within the tolerated levels. Magnesium intake level is 40.5, 48.6, 52.6, 48.6 and $43.2 \mathrm{mg} /$ day whereas suggested intake is $36 \mathrm{mg} /$ day. Suggested intake level for 6-12 months infants is 3 $\mathrm{mg} /$ day. Results indicate that Nan2 pro, Lactogen2, Meiji2, Similac2 and Nan vanilla have estimated intake value of $2.6,4.9,3.3,1.65$, and $9.8 \mathrm{mg} /$ day. Nan vanilla showed exceptionally high value. Tolerable uptake value for zinc is recommended to be $5 \mathrm{mg}$ /day Lactogen 2, Nan 2 pro and Similac 2 showed lower values. The infants from 6-12 months need larger values that are accomplished by taking cereal based food having micronutrients. All the values of daily intakes of 6 months and 1-3 years infants are shown in Figure 4, 5 and 6 gives the estimated values of daily intake of metals in different age group children. Kazi et al. 2009 studied concentrations of toxic elements (TEs), aluminum $(\mathrm{Al})$, cadmium $(\mathrm{Cd})$, and lead $(\mathrm{Pb})$ in seventeen imported samples of infant milk-based (IMF) and infant soy-based formulae (ISF). It was observed that ISF contains higher concentration of understudy toxic analytes as compared to IMF. The all three TEs, $\mathrm{Al}, \mathrm{Cd}$ and $\mathrm{Pb}$ were detected in different branded infant formulae, in the range of (1070-2170), (10.5-34.4), and (28.7-119) g/kg, respectively. The estimated intakes of TEs as $\mathrm{g} / \mathrm{kg} / \mathrm{week}$ for infants (>1 year) through milk formulae were well below the recommended tolerable levels of these elements. Generally, there is a fortification of iron in with $12 \mathrm{mg} / \mathrm{liter}$ in infant formula. Recommended daily intake is $8.5 \mathrm{mg} /$ day and tolerable uptake level is $40 \mathrm{mg}$ (Devaney et al., 2004). Estimated intake of copper is higher in Nan 2 pro, lactogen 2 and Nan vanilla samples than the recommended value that is $0.6 \mathrm{mg} /$ day. While adequate is provided by rest of products. Newborn recipes have less or more copper than provided by breast milk but mostly less. It is considered that ingestion of copper has less or no effect on milk copper concentrations (Lönnerdal, 1998). Nickel detection is not seen in Nan 2, Lactogen 2 and Mieji 2, while other 2 are in limits. The concentration that is achieved for sodium is larger in amount than it should be, that is $120 \mathrm{mg} /$ day. Potassium and magnesium has been set to the amount of 700 and $36 \mathrm{mg} /$ day but the entire calculation showed higher amount for daily ingestion. The amount of zinc recommended for kids is $4.1 \mathrm{mg} /$ day. Zinc estimation in Complan chocolate, Complan vanilla and Complan strawberry was $1.0 \mathrm{mg} /$ day on daily basis. This estimation indicates that lesser zinc is provided by these products according to our study. While other products like Kallyg's chocos, Horlicks junior and Nido bunyad indicated much lesser ingestion values. Iron and copper have been set to level that is permissible for intake as 7 and 0.56 , whereas the assessed iron intake for Horlicks wheat, Complan chocolate, Complan vanilla, Horlicks chocolate, Kallyg's' chocos, Nido bunyad and milo is $7.25,1.5,1.6,1.6,2.8$, $2.25,3.5,4.0,5.0$ and $5.25 \mathrm{mg} /$ day respectively and 0.13 , $0.20,0.15,0.10,0.08,0.25,0.05,0.07,0.17,0.125 \mathrm{mg} / \mathrm{day}$ are the values for copper intake as shown in the Figure 5, 6,7 respectively.

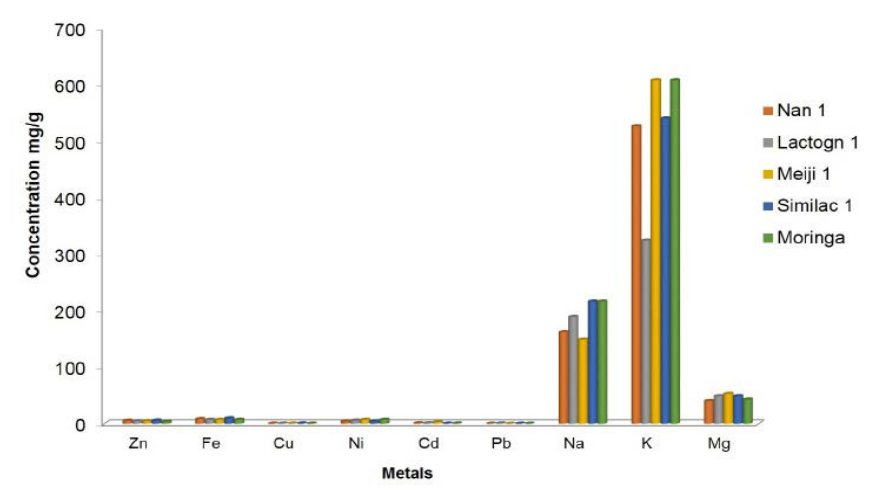

Figure 4: Estimation of daily intake of metals $\mathrm{mg} /$ day for 0-6 month's infants

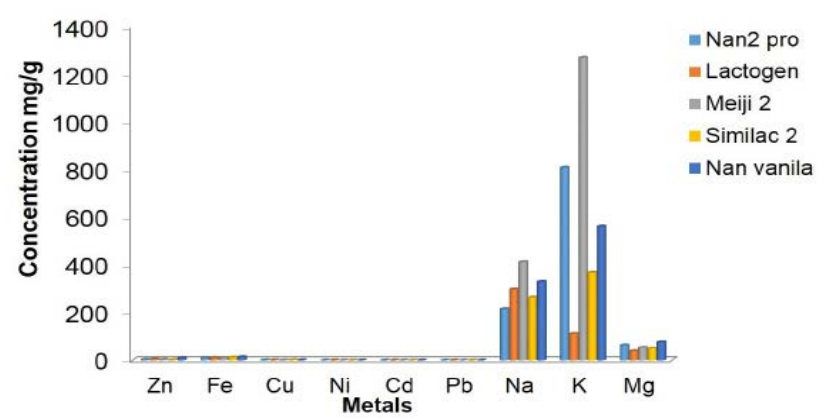

Figure 5: Estimated daily intake of metals for 6-12months infants $\mathrm{mg} / \mathrm{day}$.

Table 3: Recommended daily intake of metals for babies above 1 year (1-3year) mg/day

\begin{tabular}{|lll}
\hline Sr no. & Metals & Recommended daily intake \\
\hline 1 & Zinc & 4.1 \\
2 & Iron & 7 \\
3 & Copper & 0.56 \\
4 & Nickel & 0.15 \\
\hline 5 & Cadmium & 0.005 \\
7 & Lead & 0.06 \\
\hline 8 & Sodium & 200 \\
\hline 9 & Potassium & 800 \\
\hline 10 & Magnesium & 60 \\
\hline
\end{tabular}


In the same way declared quantity of iron per day is also lower than allowed values. Quantity for cadmium that should be ingested per day is very small and has cut off value that is $0.005 \mathrm{mg} /$ day. Complan vanilla, bournvita and milo have content of cadmium that falls in permitted quantity to be taken on a daily basis that is $0.0007,0.003$ and $0.002 \mathrm{mg} /$ day while others indicated higher content. There is a larger indication of eating lead through the above baby food products as the assessed values for daily consumption for Complan chocolate, Complan vanilla, Horlicks chocolate, Nido bunyad and milo are 1,3.5,0.25,0.5,1.0,0.1,0.0 $80.34,0.65 \mathrm{mg} /$ day. All these show that there is a greater risk of lead in these samples. Studies were done in China also reported raised contents of $\mathrm{Pb}, \mathrm{Cd}, \mathrm{Cr}, \mathrm{Cu}$, and $\mathrm{Ni}$ in tea which correlates with the results of the present study (Zhong et al., 2016).

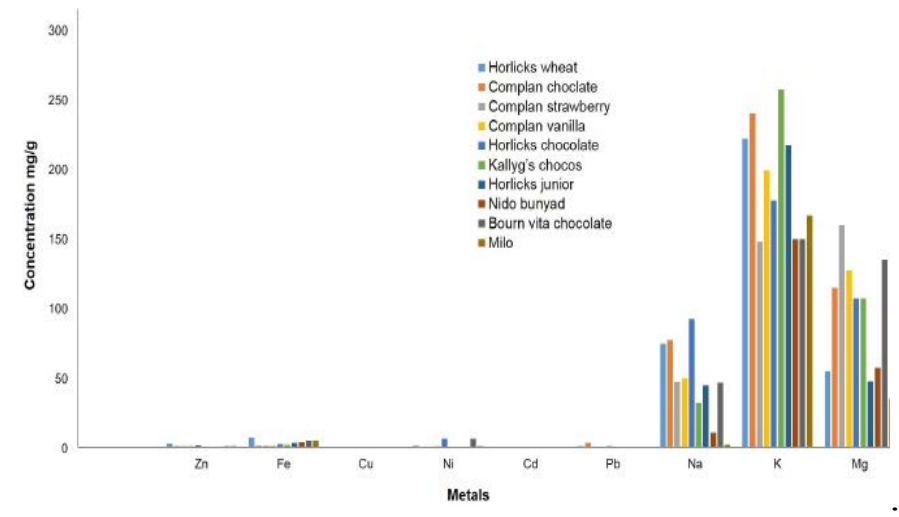

Figure 6: Estimated daily intake of children above 1 year (1-3 years) $\mathrm{mg} /$ day.

Kazi et al. 2010 conducted a research in which concentrations of toxic elements, $\mathrm{Al}, \mathrm{Cd}, \mathrm{Ni}$ and $\mathrm{Pb}$ were measured in different baby foods. The range of the investigated TEs in different BFs were 4770-35,200, 25.6-88.3, 124-332 and $52.5-90.6 \mathrm{~g} / \mathrm{kg}$ for $\mathrm{Al}, \mathrm{Cd}, \mathrm{Ni}$ and $\mathrm{Pb}$, respectively. The results indicated that BFs including rice cereals have elevated level of all four TEs. The daily intakes of TEs for children through BFs have also been estimated, and are well below the recommended tolerable levels. The levels of elements in analyzed samples were found to be under legal limits.

Other metals like strontium were also analyzed in Pakistani diet which was 1.4 times higher and $\mathrm{Ca}$ concentration was 0.4 times lower than the recommended values of the International Commission on Radiological Protection (ICRP). Analysis of the study concluded that strontium concentration in the Pakistani diet is within the requirements whereas, the calcium concentration is insufficient for growing individuals as per international standards and needs improvement in its levels (Akhter et al., 2004). To summarize in this present study sodium and potassium content for consumption on daily basis is much lower than standard consumption value $\mathrm{mg} /$ day. Complan chocolate, Complan strawberry, Complan vanilla and Horlicks chocolate are much higher in magnesium mineral as they show the level of intake beyond cut off limits that are $60 \mathrm{mg} /$ day.

\section{Protein Analysis by Lowry Method}

Samples were evaluated for protein by using Lowry method. Greater concentration was in Cerelac strawberry, cerelac 3 fruits, cerelac wheat but occurs in allowable measures whereas lowest is found in Cerelac rice (Figure 7). Tissue building an essential process of infancy requires a large amount of protein. The requirement of proteins for new born between 0-6 months and 6-12 months is 108 $(\mathrm{kcal} / \mathrm{kg})$ and $98(\mathrm{kcal} / \mathrm{kg})$ of energy respectively, on the other hand, $2.2 \mathrm{mg} / \mathrm{kg}$ and $1.5 \mathrm{mg} / \mathrm{kg}$ are daily required according to the weight of the individual. Metal such as cadmium, sodium and potassium are also found to have a strong link with proteins as these metal ions have a specific path through which they pass through protein channels.

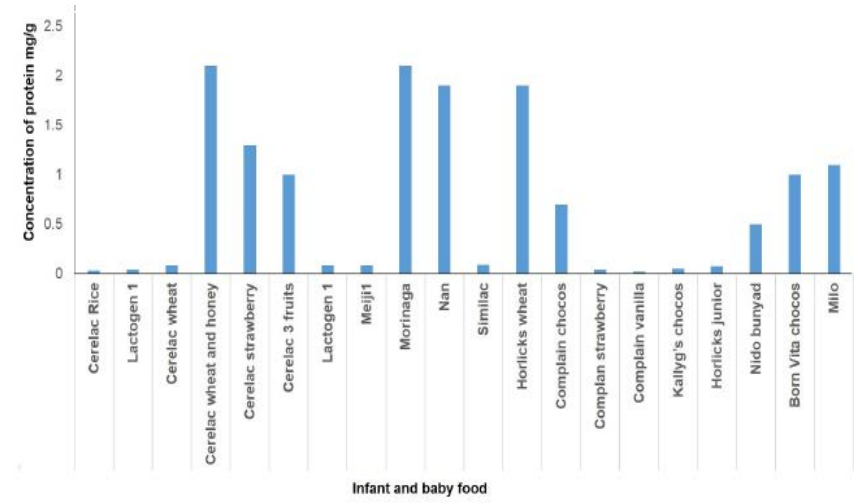

Figure 7: Graphical representation of the concentration of protein in infant and baby food.

\section{Estimation of Prebiotics}

Absorbance at $600 \mathrm{~nm}$ with antibiotic ciprofloxacin indicated bacterial growth in the samples. Cerelac wheat \& honey show greater growth in the very first hour Figure 8A. While growth decreases after the first hour and remains same after that. Meiji 1 shows greater concentration at the second hour as shown in Figure 8B. Little growth was observed after 1 hour as seen in all samples in Figure 9 $A$ and B. Whereas Nan vanilla, Cerelac strawberry shows less growth at the first hour. Absorption curves were obtained when ciprofloxacin was added that is resistant to Bifidobacterium bacteria. Ciprofloxacin allows the Bifidobacterium to grow with time but do not allow growth of other bacteria that could be present. Bacteria in the sample shows optical density in range Meiji>lactogen 1>Cerelac wheat and honey<Cerelac strawberry $<$ Nan $1<$ Cerelac wheat $<$ Cerelac $3 \mathrm{~F}<$ Cerelac rice as seen in Figure $8 \mathrm{~A} \& \mathrm{~B}$. Optical density without antibiotics showed abrupt growth of several other bacteria that can be realized by the fact 
that large amount of absorption is obtained just after 1 hour of incubation. They resulted in abrupt growth during the first hour which shows growth of many other bacteria. There were significant variations in the concentration levels of the understudy metals among the infant starter, follow up formulae and cereal based baby food. It is concluded that commercial complementary infant and baby foods in Lahore markets contain the minimum levels of metals required and for some metals the values are above the permissible limits. As per the labeling declaration of micronutrients and toxic metals like nickel and lead do not show their presence in many samples. Protein content was within limits in almost all samples. On the other hand, most of the infant formula products examined in this study contained the declared prebiotics in sufficient amounts.
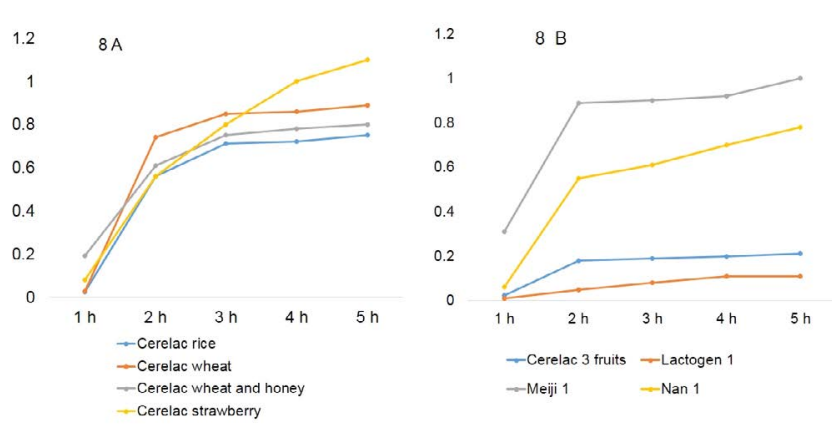

Figure 8A and B: Growth curve of bacteria in presence of ciprofloxacin.
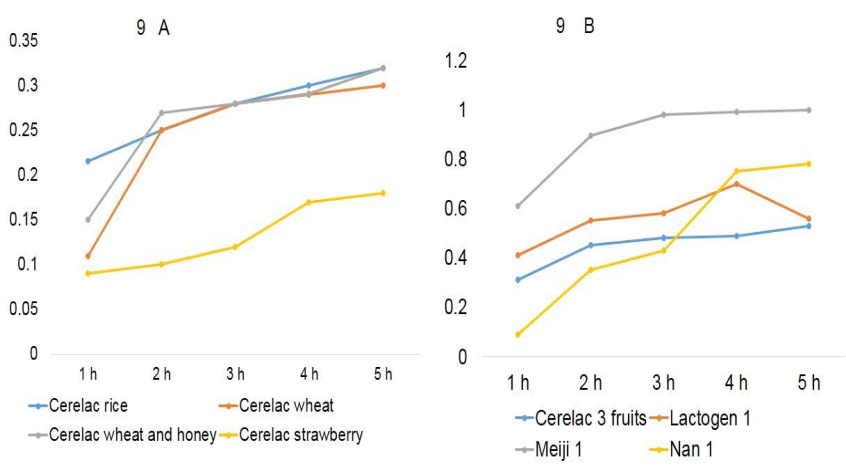

Figure 9A and B: Growth curve of bacteria in absence of ciprofloxacin.

\section{ACKNOWLEDGEMENTS}

We acknowledge the Lahore college for Women University for providing practical and financial support for this research work.

\section{CONFLICT OF INTEREST}

There in no conflict of interest.

\section{AUTHORS CONTRIBUTION}

Amina Arif: Planned this study.

Bushra khan: Provides Labs, chemicals, instruments for this research work

Amina Arif: Corresponding author.

Khizra Majeed: Performed practical work.

Muhammad Saqib Shahzad: Provided technical support for the practical work.

Muhammad Shahid Nadeem: Data Analysis, compiling and paper write up.

Rafique Ahmed : Proof read the paper, data analysis, compiling and paper formating.

\section{REFERENCES}

- Ackerberg T, Labuschagne IL, Lombard MJ (2012). The use of prebiotics and probiotics in infant formula. South African Family Practice. 54(4): 321-323. https://doi.org/10.1080/20 786204.2012.10874243

- Ahmad I,Zaman A, Samad N, Ayaz M, Rukh S (2017). Atomic Absorption Spectrophotometery Detection of Heavy Metals in Milk of Camel, Cattle, Buffalo and Goat from Various Areas of Khyber-Pakhtunkhwa (KPK). Pakistan. J. Anal. Bioanal. Tech. 8(367): 2. https://doi.org/10.4172/21559872.1000367

- Akhter P, Baloch N, Mohammad D, Orfi S, Ahmad N (2004). Assessment of strontium and calcium levels in Pakistani diet. J. Environ. Radioactiv. 73(3): 247-256. https://doi. org/10.1016/j.jenvrad.2003.08.011

- Aleixo PC, Nobrega JA (2003). Direct determination of iron and selenium in bovine milk by graphite furnace atomic absorption spectrometry. Food Chem. 83: 457-462. https:// doi.org/10.1016/S0308-8146(03)00224-3

- Briefel RR, Reidy K, Karwe V, Devaney B (2004). Feeding infants and toddlers study: Improvements needed in meeting infant feeding recommendations. J. Am. Dietetic Assoc. 104: 31-37. https://doi.org/10.1016/j.jada.2003.10.020

- Chao HH, Guo CH, Huang CB, Chen PC, Li HC, Hsiung DY, Chou YK (2014). Arsenic, cadmium, lead, and aluminium concentrations in human milk at early stages of lactation. Pediat. Neonatol. 55(2): 127-134. https://doi. org/10.1016/j.pedneo.2013.08.005

- Demirezen D, Uruç K (2006). Comparative study of trace elements in certain fish, meat and meat products. Meat Sci. 74(2): 255-260. https://doi.org/10.1016/j. meatsci.2006.03.012

- De Amorim, FR, Nascentes CC, Franco MB, da Silva JBB (2011). Fast Determination of Manganese in Milk and Similar Infant Food Samples Using Multivariate Optimization and GF AAS. Intr. J. Spectroscop. 7: 21-27. https://doi.org/10.1155/2011/810641

- Devaney B, Ziegler P, Pac S, Karwe V, Barr SI. Nutrient intakes of infants and toddlers. J. American Dietetic Ass. (2004); 104: 14-21 https://doi.org/10.1016/j.jada.2003.10.022

- Donovan S, Gibson G, Newburg D (2009). Prebiotics in infant nutrition. Mead Johson and Company. 1-42. 
- El-Batanouni MM, Abo El-Ata G (1996). Metals in food. Proceedings of Food Born Contamination and Egyptian's Health Conference. Pp. 11-25. Mansoura, Egypt

- Gasmalla MAA, Khadir K E, Musa A, Aboshora W, Zhao W (2013). Evaluation of some physicochemical parameters of three commercial milk products. Pak. J. Food Sci. 23(2): 62-65.

- Ismail A, Riaz M, Akhtar S, Farooq A, Shahzad MA, Mujtaba A (2017). Intake of Heavy Metals through Milk and Toxicity Assessment. Pak. J. Zool. 49: 1413-1419. https:// doi.org/10.17582/journal.pjz/2017.49.4.1413.1419

- Kazi TG, Jalbani N, Baig JA, Arain MB, Afridi HI, Jamali MK, Shah AQ, Memon AN (2010). Evaluation of toxic elements in baby foods commercially available in Pakistan. Food chem. 119 (4): 1313-1317. https://doi.org/10.1016/j. foodchem.2009.09.003

- Kristensen NB, Bryrup T, Allin KH, Nielsen T, Hansen TH, Pedersen O (2016). Alterations in fecal microbiota composition by probiotic supplementation in healthy adults: a systematic review of randomized controlled trials. Genome Medicine. 8 (1): 52. https://doi.org/10.1186/s13073-0160300-5

- Lönnerdal B. (1998). Copper nutrition during infancy and childhood. Am. J. Clin. Nutr. 67 (5): 1046-1053. https://doi. org/10.1093/ajcn/67.5.1046S

- Okada IA, Sakuma AM, Maio FD, Dovidauskas S, Zenebon O (1997). Evaluation of lead and cadmium levels in milk due to environmental contamination in the Paraiba Valley region of Southeastern Brazil. Revista de Saúde Pública.31(2): 140143. https://doi.org/10.1590/S0034-89101997000200006

- Pavlović I, Sikirić M, Lukač-Havranek J, Plavljanić N, Brajenović N (2004). Lead and cadmium levels in raw cow's milk from an industrialised Croatian region determined by electrothermal atomic absorption spectrometry. Czech J. Anim. Sci. 49(4): 164-168. https://doi.org/10.17221/4295CJAS

- Rodriguez EM, Alaejos SM, Romero DC (2000). Concentrations of iron, copper and zinc in human milk and powdered infant formula. Int. J. Food Sci. Nutr. 51: 373-380. https://doi.org/10.1080/096374800426966

- Sanders AP, Henn BC, Wright RO (2015). Perinatal and childhood exposure to cadmium, manganese, and metal mixtures and effects on cognition and behavior: a review of recent literature. Curr. Environ. Health Rep. 2: 284-294. https://doi.org/10.1007/s40572-015-0058-8

- Sipahi H, Eken A, Aydin A, Sahin G, Baydar T (2006). Determination of aluminum level in baby food samples by using atomic absorption spectrometer. Toxicol. Lett. 164: S271-S272. https://doi.org/10.1016/j.toxlet.2006.07.224

- Van't Land B, Boehm G, Garssen J (2010). Breast milk: components with immune modulating potential and their possible role in immune mediated disease resistance. In Dietary components and immune function. Springerplus, 20: $25-41$.

- Waterborg JH (2002). The Lowry method for protein quantitation. The protein protocols handbook. Pp. 7-9. https://doi.org/10.1385/1-59259-169-8:7

- Zhong WS, Ren T, Zhao LJ (2016). Determination of Pb (Lead), Cd (Cadmium), Cr (Chromium), Cu (Copper), and $\mathrm{Ni}$ (Nickel) in Chinese tea with high-resolution continuum source graphite furnace atomic absorption spectrometry. J. Food Drug Analy. 24(1): 46-55. https://doi.org/10.1016/j. jfda.2015.04.010 